\title{
The Interrelationship of Agronomic and Physiological Traits as Affected by Irrigation Regimes in Wheat: Application of Multivariate Statistical Analyses
}

\author{
Samaneh Zamani-Babgohari, Bahram Heidari*, Ali Dadkhodaie \\ Department of Crop Production and Plant Breeding, School of Agriculture, 71441-65186, Shiraz University, Shiraz, Iran
}

\begin{abstract}
Understanding the interrelationships between agronomic and water status characters helps development of drought tolerant cultivars. In the present study, 34 wheat genotypes were used to investigate joint variability of water status characters and yield related traits under normal irrigation regimes and drought stress in 2014-2015 growing season. The results indicated that selection of genotypes based on loadings in factors number 1, 3 and 4 would be of beneficial in terms of increasing grain yield related traits under drought stress conditions. In canonical correlation analysis (CCA), the first (U1, V1) and second (U2, V2) pairs canonical variables (CV) explained $75 \%$ and $67 \%$ of the total joint variability of agronomic and physiological traits under drought stress conditions, respectively. The first (V1) physiological CV that had positive correlation with water saturated deficit (WSD, $r=0.63$ ) and excised leaf water loss (ELWL, $r=0.35$ ) was more correlated with grain yield and harvest index under drought stress. The second (V2) physiological CV which was more influenced by variations in initial water content (IWC, $r=0.6)$ and leaf water content (LWC, $r=$ 0.65 ) was associated with spike length and spikelet per spike variations. Significant between-groups mean squares advocated that classification of genotypes into four groups was the best possible branching under both conditions. Therefore, making crosses between genotypes of cluster numbers 1 (with high grain yield and its components) and 3 (having shortest height) can be used for the production of extreme or novel phenotypes for grain yield and dwarfness in the progenitors in further breeding programs for drought tolerance.
\end{abstract}

Keywords Canonical variables, Joint variability, Water-related traits, Factor analysis

\section{INTRODUCTION}

Plants are constantly exposed to various abiotic stresses threatening their growth and development (Tas and Tas 2007; Hamayun et al. 2010; Subhani et al. 2011; Atkinson and Urwin 2012). Over the past 30 years (1986-2016), southwestern Iran specifically Fars province has experienced severe drought conditions. An analysis of the long-term rainfall data indicates that the recent drought was preceded by several droughts in Fars province. Between May and October which is coincident with anthesis and heading occurrence in wheat fields, rain is rare in this region (Hojjati and Boustani 2010). Developing high yielding cultivars is the best strategy to deal with drought stress that depends upon understanding the factors that affect grain yield. Physiological traits relevant for the responses to drought span a wide range of processes that shows no single response pattern are highly correlated with grain yield under drought conditions (Cattivelli et al. 2008). The identification of key factors and patterns of joint variability in agronomic and physiological traits under drought can demonstrate a picture on how the factors contribute to final grain yield in a consorted way (Gian et al. 2009). Multivariate analysis tools can be used to quantify the interrelationship between such contrast traits and a better understanding of the effects of physiological

Received May 13, 2017; Revised July 16, 2017; Accepted July 31, 2017; Published September 1, 2017

*Corresponding author Bahram Heidari, bheidari@shirazu.ac.ir, Tel: +98-36138176, Fax: +98-32286134 
variations on wheat agronomic traits at regional scale.

Most of studies covering the effects of drought stress have focused on investigation for agronomic or physiological variations under drought conditions and relatively less effort has been devoted to joint variability of these factors at different growth stages (Cattivelli et al. 2008; Reynolds et al. 2009; Sangtarash 2010; Ahmadizadeh et al. 2011; Mollasadeghi et al. 2011; Ghaed-rahimi et al. 2015; Mirtaheri et al. 2015; Dorostkar et al. 2016). In a study on wheat, multivariate analysis tools were applied for evaluation of cultivars response to drought stress using variations in agronomic traits but no physiological characteristic was included (Mirtaheri et al. 2015). In Mollasadeghi et al. (2011), three hidden factors associated with yield potential, harvest index and phenological factor accounted for $88 \%$ of the total variability in wheat under drought stress conditions. Leila and Al-Kateeb (2005) used seven statistical procedures including path coefficients, regression, factor analysis and principal components analysis (PCA) to investigate the interrelationships between agronomic traits. They concluded that breeding programs on the basis of variations in spikes $/ \mathrm{m}^{2}, 1000$-grain weight and grain weight per spike would be more reasonable to develop high yielding cultivars under drought stress in an area in the Kingdom of Saudi Arabia. In evaluation of wheat recombinant inbred lines (RILs) for the consequences of 1BL/1RS translocation, Tahmasebi et al. (2015) assessed some agronomic and physiological traits but no joint analysis was performed for the interrelationship between traits under drought and heat stress conditions. Although Ordaz-Oritz et al. (2005) focused on PCA and clustering methods for classification of wheat cultivars based on structural features of arabinoxylans, they have not used canonical correlation analysis (CCA) to interpret the results. Nonetheless, in few studies CCA had been used to joint variations of contrast traits. In Qian et al. (2009), CCA was performed to identify the mode of variation of the water-related variables that is closely associated with internal variability of regional spring wheat yields. The results of CCA indicated that the water-related factors at the jointing heading-soft dough stage favored spring wheat yields in three provinces in Canada (Qian et al. 2009).

The basic concept of multivariable analysis is to recognize applied connections among the variables to reduce a large number of correlative traits to a few numbers of factors explaining the correlation among the variables (Bramel et al. 1984; Zakizadeh et al. 2010). After an extensive literature review we found few studies on of multivariate analysis to quantify the interrelationship between physiological and agronomic traits under drought stress condition. Therefore, the present study aimed at the application of multivariate analyses for a better understanding of the effects of drought stress on the interrelationships of agronomic and physiological traits through the joint variability of such characteristics in three types of wheat entries.

\section{MATERIALS AND METHODS}

\section{Plant material and experimental design layout}

The present study was conducted during the 2014-2015 growing season at the Research Farm of Shiraz University $\left(52^{\circ} 32^{\prime}\right.$ E $\left.29^{\circ} 36^{\prime} \mathrm{N}\right)$, Iran. Seven Iranian commercial cultivars, three Swiss lines and 23 landrace varieties were used for sowing. Code, type and maturity of genotypes are displayed in Table 1. Commercial cultivars were well-known wheat that had been used for cultivation in southern regions of Iran suffering from low precipitations during growing season. The landrace varieties, collected from different regions of Iran, were highly variable morphologically and introduced from a pre-screening of 200 initial landrace varieties in a collaborative breeding program under field experiments conditions in Shiraz University (Khaledian et al. 2014; Dorostkar et al. 2015; Ghaed-rahimi et al. 2015). The landraces were collected by the Seed and Plant Improvement Institute (SPII), Karaj, Iran.

Prior to sowing, the field was fertilized with $300 \mathrm{~kg}$ urea $(46 \% \mathrm{~N}) / \mathrm{ha}$ and $110 \mathrm{~kg} / \mathrm{ha}$ triple superphosphate. During the growing season, $50 \mathrm{~kg} \mathrm{~N} / \mathrm{ha}$ were applied at both the stem elongation and heading stages. The soil texture was silt loam with $\mathrm{pH} 7, \mathrm{EC}(0.61 \mathrm{dS} / \mathrm{m}), \mathrm{CEC}(0.52 \mathrm{dS} / \mathrm{m})$, total N $(0.091 \%)$, available P $(21.8 \mathrm{mg} / \mathrm{kg}), \mathrm{K}(600 \mathrm{mg} / \mathrm{kg})$, OC $(0.96 \%$ at $0-15 \mathrm{~cm}$ soil depth) and FC (28.6\%). Each experimental plot was $3 \times 2 \mathrm{~m}$ in size. On November 2014, the seeds were sown at a depth of $5 \mathrm{~cm}$ with a density of 
$350 \mathrm{seed} / \mathrm{m}^{2}$. Weeding was performed using $25 \mathrm{~g} / \mathrm{ha}$ Granstar ${ }^{\mathbb{R}}$ herbicide at tillering stage and by hand pulling at all stages of wheat growth. The Decis ${ }^{\circledR}$ insecticide (300 $\mathrm{mL} / \mathrm{ha}^{-1}$ ) was used to control stink bug. The experimental layout was arranged as a split plot based on a randomized complete block design (RCBD) with three replications. In the layout of experimental design, the main plots allocated

Table 1. Code, type and maturity of wheat genotypes.

\begin{tabular}{clll}
\hline \hline Code & Genotype & \multicolumn{1}{c}{ Type $^{\text {) }}$} & Maturity \\
\hline 1 & Pyshtaz & Commercial & Late \\
2 & Mihan & Commercial & Late \\
3 & Chamran & Commercial & Early \\
4 & Sirvan & Commercial & Late \\
5 & Shiroodi & Commercial & Late \\
6 & Shiraz & Commercial & Late \\
7 & Cross-bolani & Commercial & Late \\
8 & BA15 & Swiss & Late \\
9 & BA13 & Swiss & Late \\
10 & SPQ757 & Swiss & Late \\
11 & KC3891 & Landrace & Early \\
12 & KC3892 & Landrace & Early \\
13 & KC3893 & Landrace & Early \\
14 & KC4929 & Landrace & Early \\
15 & KC4848 & Landrace & Early \\
16 & KC4856 & Landrace & Early \\
17 & KC4863 & Landrace & Early \\
18 & KC4512 & Landrace & Late \\
19 & KC4567 & Landrace & Intermediate \\
20 & KC4580 & Landrace & Intermediate \\
21 & KC4528 & Landrace & Intermediate \\
22 & KC4537 & Landrace & Early \\
23 & KC4557 & Landrace & Early \\
24 & KC4551 & Landrace & Early \\
25 & KC4552 & Landrace & Early \\
26 & KC4642 & Landrace & Late \\
27 & KC4641 & Landrace & Intermediate \\
28 & KC4604 & Landrace & Late \\
29 & KC4630 & Landrace & Early \\
30 & KC4633 & Landrace & Early \\
31 & KC4492 & Landrace & Late \\
32 & KC2165 & Landrace & Late \\
33 & KC4144 & Landrace & Late \\
\hline & & & \\
\hline
\end{tabular}

${ }^{2)}$ Commercial: Commercial cultivars were well-known wheat that had been used for cultivation in southern regions of Iran, Swiss: Swiss lines are semi-dwarf genotypes that had been used in breeding program in Switzerland for improved disease resistance, and Landrace: the landrace varieties, collected from different regions of Iran. to the fully irrigated regime (field capacity) and drought stress, and genotypes were assigned to the sub plots. In plots allocated to drought stress, plants were fully watered until $50 \%$ of genotypes headed and irrigation practice was stopped until harvesting plants on 1-2 July. From heading the region have been frequently suffered from rare or no precipitation.

\section{Data for agronomic traits}

Some of agronomic traits including plant height $(\mathrm{cm})$ and spike length $(\mathrm{cm})$ were measured after pollination in 10 individual plants selected from the middle rows of each plot after irrigation stop. The data for grain yield and its components was collected after harvesting. Spike yield $\left(\mathrm{g} / \mathrm{m}^{2}\right)$, number of spikelet per spike, grains number per spike, thousand grain weight, biological yield $\left(\mathrm{g} / \mathrm{m}^{2}\right)$, grain yield $\left(\mathrm{g} / \mathrm{m}^{2}\right)$ and harvest index $\left(\frac{\text { Grian yield }}{\text { Biological yield }} \%\right)$ were measured for each genotype in both normal irrigation and drought stressed experimental plots. After hand harvesting from the field, grain yield at $14 \%$ moisture was measured as g per square meter.

\section{Data for physiological traits}

Two weeks after irrigation stop in the trial field some physiological traits including initial water content (IWC), relative water content (RWC), water saturated deficit (WSD), leaf water content (LWC) and excised leaf water loss (ELWL) were measured in leaf of each genotype. RWC (Barrs and Kozlowski 1968), WSD (Barrs and Kozlowski 1968), IWC (Clarke and McCaig 1982), LWC (Clarke and McCaig 1982) and ELWL (Clarke et al. 1989) were calculated following formulas as below:

$$
\begin{aligned}
& \mathrm{RWC}=\frac{\mathrm{WF}-\mathrm{WD}}{\mathrm{WT}-\mathrm{WD}} \\
& \mathrm{WSD}=\frac{\mathrm{WT}-\mathrm{WF}}{\mathrm{WT}-\mathrm{WD}} \\
& \mathrm{IWC}=\frac{\mathrm{WF}-\mathrm{WD}}{\mathrm{WD}} \\
& \mathrm{LWC}=\frac{\mathrm{WF}-\mathrm{WD}}{\mathrm{WF}} \\
& \mathrm{ELWL}=\frac{\mathrm{WF}-\mathrm{W} 1}{\mathrm{WF}-\mathrm{WD}}
\end{aligned}
$$

where, WF, WD, WT and W1 stand for leaf fresh weight 
(g), dry weight ( $\mathrm{g}$ ), turgor weight $(\mathrm{g})$ and the weight $(\mathrm{g})$ of excised leaves after 2 hours in $28^{\circ} \mathrm{C}$ in incubator.

\section{Data analysis}

The data were initially subjected to analysis of variance (ANOVA) to estimate mean squares for the sources of variation. This was performed using PROC GLM statement associated with split plot design in SAS software (SAS Institute V.9.2). Simple correlation coefficients between agronomic traits were calculated for each drought stress and irrigation regime conditions. Multivariate analyses including cluster analysis, factor analysis and canonical correlation analysis (CCA) were also performed. PROC CANCORR was used to perform CCA for the two sets of agronomic (X) and water status (Y) characteristics. CCA developed by Hotelling (1936), often allows a more meaningful interpretation of interrelations between variables than simple correlation analysis. CCA utilizes two sets of variables $(\mathrm{X}$ and $\mathrm{Y})$ to construct linear combinations for the first and second sets as $\mathrm{U}=\mathrm{a}^{\prime} \mathrm{X}$ and $\mathrm{V}=\mathrm{b}^{\prime} \mathrm{Y}$, respectively. Where, $a^{\prime}$ and $b^{\prime}$ are the canonical coefficients vectors. In $\mathrm{CCA}$, the variance-covariance of the original variables $(\mathrm{X}$, $\mathrm{Y})$ is partitioned as:

$$
S=\left[\begin{array}{ll}
S x x & S y y \\
S x y & S y y
\end{array}\right]
$$

Therefore, the variance of the sets $(\mathrm{U}, \mathrm{V})$ and the covariance between them are defined as:

$$
\begin{aligned}
& \operatorname{Var}(\mathrm{U})=\mathrm{a}^{\prime} \text { Sxx } a \\
& \operatorname{Var}(\mathrm{V})=\mathrm{b}^{\prime} \text { Syy } b
\end{aligned}
$$

\section{$\operatorname{Cov}(\mathrm{U}, \mathrm{V})=\mathrm{a}^{\prime} \mathrm{Sxy} \mathrm{b}$}

The canonical correlation coefficient between $\mathrm{U}$ and $\mathrm{V}$ can be expressed as:

$$
r(U, V)=\frac{\mathrm{a}^{\prime} \text { Sxyb }}{\left(\sqrt{\mathrm{a}^{\prime} \text { Sxxa }}\right)\left(\sqrt{\mathrm{b}^{\prime} \text { Syy }}\right)}
$$

In this study we used nine agronomic and five physiological traits as the two sets of variables for CCA and better interpreting of the interrelationships between them. To do this, we defined agronomic traits (Agro) as $\mathrm{U}$ and physiological traits (Physio) as V variables. Correlations of each of original traits with their canonical variables (Agro and Physio) and with cross canonical variables were calculated.

In factor analysis, factor loadings for each trait and the contribution of each factor in total variation were determined using ROTATE $=$ VARIMAX option in PROC FACTOR statement. The number of effective factors was determined using a biplot in the projection of eigenvalues against factor number. Classification of genotypes was performed using the Ward (1963) linkage method and similarities of genotypes based on Euclidean distances for agronomic traits in Minitab software (Minitab 17 Statistical Software, www.minitab.com).

\section{RESULTS}

\section{Weather conditions at the trial site}

The meteorological data for the trial site are summarized in Table 2. The data show that most precipitation during the

Table 2. The meteorology data for the trial filed at School of Agriculture, Shiraz University, Iran in 2014-2015 growing season.

\begin{tabular}{lcccr}
\hline \hline \multirow{2}{*}{ Month } & \multicolumn{3}{c}{ Temperature $\left({ }^{\circ} \mathrm{C}\right)$} & Precipitation $(\mathrm{mm})$ \\
\cline { 2 - 4 } & Max & Min & Average & 27.0 \\
October & 26.5 & -6.0 & 9.3 & 50.5 \\
November & 25.0 & -5.8 & 6.3 & 11.0 \\
December & 18.5 & -10.0 & 5.2 & 48.8 \\
January & 20.0 & -7.0 & 8.4 & 45.0 \\
February & 20.0 & -7.4 & 7.4 & 39.5 \\
March & 27.0 & -2.5 & 13.6 & 10.0 \\
April & 31.0 & 1.6 & 22.0 & 0.0 \\
May & 36.0 & 7.0 & 28.9 & 0.0 \\
June & 38.0 & 13.0 & & 231.0 \\
Total & & & & \\
\hline
\end{tabular}


vegetative stage occurred from November to February. In an interval from April to June which was coincident with generative stages of wheat growth little or no precipitation was occurred. Meteorological data showed that the trial field experienced hot temperatures exceeding $30^{\circ} \mathrm{C}$ between April and June that exacerbated the effects of low precipitation or drought on wheat growth.

\section{Hidden factors responsible for traits interrelations}

Projection of each factor on its corresponding eigenvalue indicated that selection of three factors under irrigation and four factors under drought stress conditions was statistically sufficient for interpreting interrelationship of traits. Loadings for the rotated factors under irrigation and drought stress conditions are summarized in Table 3. Factors explained cumulatively $58.6 \%$ and $64.0 \%$ of the total variation of traits under irrigation and drought stress conditions, respectively. Under irrigation condition, biological yield, spike yield and grain yield had the highest loadings for the first factor indicating that this factor can be called yield factor. Factor loadings in the first factor show the relatedness between this factor and grain yield related traits. In the second factor, a loading of 0.95 for grain number per spike distinctly differentiated this trait from others.

Loadings of factors under drought stress condition revealed that the factors number 1, 3 and 4 can be called as biological yield, spike length and grain number, respectively (Table 3). Loadings in factor 2 were negligible for most of trait except grain yield which was negative $(-0.82)$. Selection of genotypes on the basis of loadings in factors number 1, 3 and 4 would be of beneficial in terms of increasing grain yield related traits under drought stress conditions.

\section{Cluster analysis}

Tree dendrogram of genotypes for irrigation and drought stress conditions are displayed in Figs.1 and 2. Significant between - group mean squares advocated that classification of genotypes into four groups were the best possible clustering on the basis of Ward similarity coefficients under both conditions (Table 4). Means for traits in different clusters indicated that the fourth group of genotypes had highest biological yield $\left(1119.6 \mathrm{~g} / \mathrm{m}^{2}\right)$, spike yield $\left(623.7 \mathrm{~g} / \mathrm{m}^{2}\right)$, harvest index $(46.6 \%)$, grains per spike (47.6) and thousand grain weight ( $45.7 \mathrm{~g}$ ) under irrigation regime. The shortest plants were categorized in cluster number 3 with 41.1 height in $\mathrm{cm}$. Highest spike length $(13.14 \mathrm{~cm})$ belonged to cluster number 2 .

Under drought stress, cluster number 1 had the highest grain yield $\left(85.0 \mathrm{~g} / \mathrm{m}^{2}\right)$, harvest index $(38.5 \%)$, spike length $(9.97 \mathrm{~cm})$, spikelet per spike (15.3), and grains per spike

Table 3. Factor loadings based agronomic traits in wheat genotypes under irrigation regime (three factors) and drought stress (four factors in parenthesis) condition.

\begin{tabular}{lcccc}
\hline \multirow{2}{*}{\multicolumn{1}{c}{ Traits }} & \multicolumn{4}{c}{ Factor loading } \\
\cline { 2 - 5 } & Factor 1 & Factor 2 & Factor 3 & Factor 4 \\
\hline Biological yield & $0.94(0.97)^{\mathrm{z})}$ & $0.05(0.023)$ & $-0.088(0.044)$ & $(0.13)$ \\
Spike yield & $0.92(0.74)$ & $0.08(-0.19)$ & $-0.11(0.29)$ & $(-0.10)$ \\
Harvest index & $0.60(-0.14)$ & $-0.19(-0.14)$ & $0.18(0.008)$ & $(-0.038)$ \\
Thousand grain weight & $0.30(0.049)$ & $-0.097(0.049)$ & $-0.28(0.12)$ & $(0.014)$ \\
Grain yield & $0.89(0.49)$ & $-0.15(-0.82)$ & $0.025(0.054)$ & $(0.077)$ \\
Spike length & $0.07(0.13)$ & $0.10(-0.023)$ & $-0.91(0.93)$ & $(0.078)$ \\
Grain number per spike & $0.16(0.087)$ & $0.95(0.077)$ & $0.08(0.059)$ & $(0.92)$ \\
Number of spikelet per spike & $-0.07(0.043)$ & $-0.12(-0.07)$ & $-0.18(0.17)$ & $(0.42)$ \\
Plant height & $0.32(0.25)$ & $0.21(-0.09)$ & $-0.24(0.30)$ & $(-0.08)$ \\
Proportion of explain variation $(\%)$ & $34.9(20.6)$ & $11.9(19.1)$ & $11.8(12.2)$ & $(12.1)$ \\
Cumulative proportion $(\%)$ & $34.9(20.6)$ & $46.8(39.7)$ & $58.6(51.9)$ & $(64.0)$ \\
\hline
\end{tabular}

${ }^{\mathrm{z})}$ Values in parenthesis refer to factors loading under drought stress conditions. For irrigation regime, only three factors were selected. 
Dendrogram

Ward Linkage; Euclidean Distance

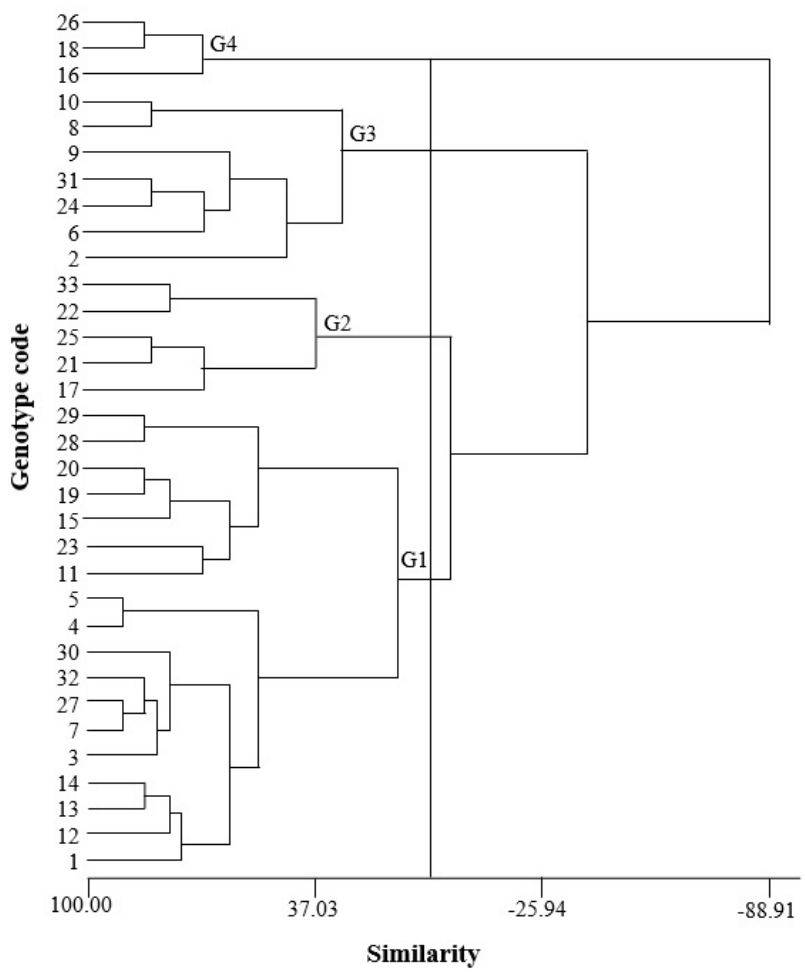

Fig. 1. Similarities of genotypes based on Euclidean distances for agronomic traits collected under irrigation condition. Numbers refer to the code of genotypes in Table 1 .
Dendrogram

Ward Linkage; Euclidean Distance

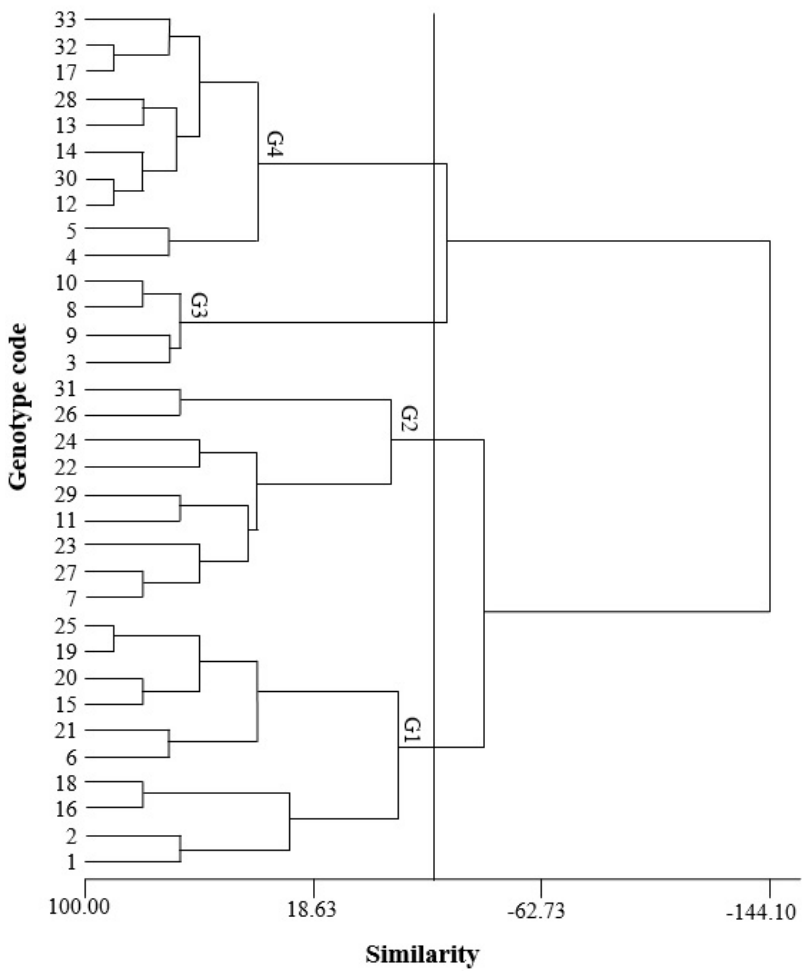

Fig. 2. Similarities of genotypes based on Euclidean distances for agronomic traits collected under drought condition. Numbers refer to the code of genotypes in Table 1.

Table 4. Mean of traits in each cluster of genotypes under irrigation regime and drought condition in wheat.

\begin{tabular}{|c|c|c|c|c|c|c|c|c|}
\hline & \multicolumn{4}{|c|}{ Irrigation regime } & \multicolumn{4}{|c|}{ Drought stress } \\
\hline & Cluster $1^{\text {z) }}$ & Cluster 2 & Cluster 3 & Cluster 4 & Cluster $1^{\mathrm{z})}$ & Cluster 2 & Cluster 3 & Cluster 4 \\
\hline Biological yield $\left(\mathrm{g} / \mathrm{m}^{2}\right)$ & $649.6 b$ & $619.7 b$ & $517.1 \mathrm{~b}$ & $1119.6 \mathrm{a}$ & $221.7 \mathrm{a}$ & $247.8 \mathrm{a}$ & $151.3 \mathrm{~b}$ & $173.5 b$ \\
\hline Spike yield $\left(\mathrm{g} / \mathrm{m}^{2}\right)$ & $408.8 b$ & $407.8 \mathrm{~b}$ & $327.7 \mathrm{~b}$ & $623.7 \mathrm{a}$ & $113.4 \mathrm{ab}$ & $122.5 \mathrm{a}$ & $85.1 \mathrm{c}$ & $85.6 \mathrm{c}$ \\
\hline Grain yield $\left(\mathrm{g} / \mathrm{m}^{2}\right)$ & $216.0 \mathrm{a}$ & $187.7 \mathrm{~b}$ & $177.7 \mathrm{~b}$ & $522.2 b$ & $85.0 \mathrm{a}$ & $61.7 \mathrm{~b}$ & $43.7 b$ & $46.6 \mathrm{~b}$ \\
\hline Harvest index $(\%)$ & $32.8 \mathrm{~b}$ & $29.5 \mathrm{~b}$ & $33.5 \mathrm{~b}$ & $46.6 \mathrm{a}$ & $38.5 \mathrm{a}$ & $25.9 \mathrm{~b}$ & $29.2 \mathrm{ac}$ & $27.3 \mathrm{~b}$ \\
\hline Plant height $(\mathrm{cm})$ & $60.0 \mathrm{a}$ & $66.2 \mathrm{a}$ & $41.1 \mathrm{a}$ & $68.6 \mathrm{a}$ & $57.2 \mathrm{a}$ & $57.0 \mathrm{a}$ & $31.4 \mathrm{~b}$ & $53.8 \mathrm{a}$ \\
\hline Spike length $(\mathrm{cm})$ & $9.54 b$ & $13.14 \mathrm{a}$ & $9.10 \mathrm{~b}$ & $10.11 \mathrm{~b}$ & $9.97 \mathrm{a}$ & $9.78 \mathrm{a}$ & $8.0 \mathrm{~b}$ & $8.4 \mathrm{ab}$ \\
\hline Spikelet per spike & $15.1 \mathrm{~b}$ & $16.6 \mathrm{a}$ & $16.7 \mathrm{a}$ & $15.1 \mathrm{a}$ & $15.3 \mathrm{a}$ & $13.4 \mathrm{~b}$ & $13.7 \mathrm{~b}$ & $13.6 \mathrm{~b}$ \\
\hline Grains per spike & $37.3 \mathrm{a}$ & $35.4 \mathrm{ab}$ & $45.5 \mathrm{ab}$ & $47.6 \mathrm{a}$ & $37.4 \mathrm{a}$ & $28.3 \mathrm{~b}$ & $30.3 b$ & $28.1 \mathrm{~b}$ \\
\hline Thousand grain weight $(\mathrm{g})$ & $40.1 \mathrm{ab}$ & $45.4 \mathrm{a}$ & $34.6 \mathrm{~b}$ & $45.7 \mathrm{a}$ & $35.5 \mathrm{a}$ & $34.2 \mathrm{a}$ & $24.8 \mathrm{~b}$ & $36.1 \mathrm{a}$ \\
\hline
\end{tabular}

${ }^{\mathrm{z})}$ Means within a column followed by different letters indicated a significant difference at the $5 \%$ by LSD test. 
(37.4). The lowest plant height was belonged to cluster number $3(31.4 \mathrm{~cm})$. Cluster number 4 had the highest magnitude $(36.1 \mathrm{~g})$ for thousands grain weight.

\section{Simple correlations between agronomic traits}

Grain yield had strong correlations with spike yield $\left(r=0.87^{* *}\right)$, harvest index $\left(r=0.82^{* *}\right)$ and biological yield $(r=0.92 * *)$ under irrigation regimes (Table 5$)$. Grain yield was also correlated with grain number, plant height and thousand grain weight. Under drought stress conditions, grain yield was correlated with plant height $\left(r=0.39^{*}\right)$, biological yield $\left(r=0.51^{* *}\right)$, spike yield $\left(r=0.58^{* *}\right)$ and harvest index $(r=0.74 * *)$.

\section{Canonical correlation analysis (CCA)}

Under drought stress condition, the first (U1, V1) and second (U2, V2) pairs of canonical variables explained $75 \%$ and $67 \%$ of the total variance, respectively (Table 6).

Therefore, the first pair of canonical variates was better predictors of the opposite set of variables. The highest coefficients in the first canonical (Agro1) variate for agronomic traits were related to spike yield $(r=0.66)$ and grains per spike $(r=0.44)$. In Agro2, biological yield had the highest $(r=0.80)$ coefficient. In Physio1 and Physio2, LWC $(r=1.44)$ and RWC $(r=-0.82)$ had the highest coefficients, respectively. Agro1 had relatively strong correlations with grain yield $(r=0.63)$ and harvest index $(r=0.7)$ while it had negative correlations with plant and spike lengths. Agro2 was strongly correlated with spike length $(r=0.74)$ and spikelet per spike $(r=0.64)$. Other traits had correlations lower than 0.5 with Agro2. Physio1 (V1) had positive correlation $(r=0.63)$ with WSD and ELWL $(r=0.35)$. Physio1 had negative or negligible correlations with other physiological variables.

Phyiso2 (V2) had high correlations with IWC $(r=0.73)$ and LWC $(r=0.78)$. Correlation of a canonical variate with opposite variables can be used for better understanding of joint variations between two sets of variables. Physio1 which was influenced by WSD and ELWL had higher correlations with grain yield and harvest index that shows joint variability of WSD, ELWL and grain yield under drought stress conditions. This relationship was confirmed by higher correlation of Agro1 with WSD. Physio2 which was more influenced by variations in IWC and LWC had higher correlations with spike length and spikelet per spike.

\section{DISCUSSION}

The present study aimed at the assessment of interrelationship of agronomic and physiological traits under normal irrigation regime and drought stress conditions in southwestern Iran. Wheat crops in these regions experience high temperatures often exceeded $30^{\circ} \mathrm{C}$ and drought stress conditions during reproductive stages of development, leading to a significant yield loss. Results of factor analysis

Table 5. The correlation coefficients of agronomic traits under fully irrigated (above diagonal) and drought stress (under diagonal) conditions.

\begin{tabular}{llllllllll}
\hline \hline Traits $^{\mathrm{z}}$ & PH & SPS & GN & SL & TGW & HI & SY & BY & GY \\
\hline GY & $0.41^{* *}$ & 0.10 & $0.30^{*}$ & 0.042 & $0.42^{*}$ & $0.82^{* *}$ & $0.87^{* *}$ & $0.92^{* *}$ & 1 \\
BY & $0.55^{* *}$ & -0.14 & 0.18 & 0.18 & $0.49^{* *}$ & $-0.60^{* *}$ & $0.92^{* *}$ & 1 & $0.51^{* *}$ \\
SY & $0.52^{* *}$ & 0.02 & 0.18 & 0.24 & $0.53^{* *}$ & $0.62^{* *}$ & 1 & $0.71^{* *}$ & $0.58^{* *}$ \\
HI & 0.08 & 0.02 & $0.34^{*}$ & -0.19 & 0.15 & 1 & 0.10 & -0.15 & $0.74^{* *}$ \\
TGW & $0.65^{* *}$ & 0.16 & 0.14 & $0.54^{* *}$ & 1 & 0.13 & 0.12 & 0.13 & 0.15 \\
SL & $0.45^{* *}$ & $0.41^{* *}$ & -0.11 & 1 & $0.31^{*}$ & 0.03 & $0.45^{* *}$ & -0.22 & 0.20 \\
GN & -0.21 & 0.21 & 1 & 0.17 & 0.03 & 0.11 & 0.02 & 0.19 & 0.18 \\
SPS & 0.06 & 1 & $0.70^{* *}$ & $0.35^{*}$ & 0.07 & 0.13 & 0.19 & 0.10 & 0.17 \\
PH & 1 & 0.12 & -0.07 & $0.57^{* *}$ & $0.47^{* *}$ & 0.06 & $0.43^{* *}$ & $0.39^{*}$ & $0.39^{*}$ \\
\hline
\end{tabular}

* and ** significant at the 0.05 and 0.01 probability level, respectively.

${ }^{2)}$ GY: grain yield, BY: biological yield, SY: spike yield, HI: harvest index, TGW: thousand grain weight, SL: spike length, GN: grain number per spike, SPS: spikelet per spike, PH: plant height. 
for joint variability of traits indicated that loadings in three factors could be used for better understanding of the interrelationship of traits increasing grain yield under drought stress conditions. Factors explained cumulatively $58.6 \%$ and $64.0 \%$ of the total variations of traits under irrigation and drought stress conditions, respectively. In Ebrahimnejad and Rameeh (2016), the factor which made the largest contribution $(50 \%)$ to the total variation was composed of grain yield, biological yield, spike weight, grain weight, spikelet per spike and grain number. The development of drought-tolerant genotypes as well as genotypes with higher water-use efficiency (WUE) is of global interest due to a rapid decrease in water resources destined to agriculture (Araus et al. 2008). A large number of morphological and physiological traits have been found to be linked to drought tolerance in cereals (Condon et al. 2004; Reynolds et al. 2005; Araus et al. 2008; Mora et al. 2015; Mwadzingeni et al. 2017).

In cluster analysis genotypes were classified based on agronomic traits and the results indicated that investigations in the progenitors of the crosses between genotypes of cluster number 1 with high grain yield and its components and cluster number 3 (having shortest height) can be efficient for developing extreme phenotypes, dwarf and high yielding genotypes in further breeding for drought tolerance. The generation of extreme phenotypes is referred to as transgressive segregation and this is a major mechanism by which novel adaptations or traits in new cultivars are thought to arise (Rieseberg et al. 1999). In the present study, in Physio1 and Physio2 canonical variables

Table 6. Standardized canonical variables (Agro and Physio) and their correlation with agronomic and physiologic traits in wheat genotypes under drought stress.

\begin{tabular}{|c|c|c|c|c|c|c|}
\hline \multirow{2}{*}{$\frac{\text { Variable }}{\text { Agronomic traits (Agr) }}$} & \multicolumn{2}{|c|}{$\begin{array}{c}\text { Coefficients in } \\
\text { canonical variables }\end{array}$} & \multicolumn{2}{|c|}{$\begin{array}{l}\text { Correlation with } \\
\text { Agro variable }\end{array}$} & \multicolumn{2}{|c|}{$\begin{array}{l}\text { Correlation with } \\
\text { Physio variable }\end{array}$} \\
\hline & $\begin{array}{l}\text { Agro1 } \\
\text { (U1) }\end{array}$ & $\begin{array}{l}\text { Agro2 } \\
\text { (U2) }\end{array}$ & Agro1(U1) & $\begin{array}{l}\text { Agro2 } \\
\text { (U2) }\end{array}$ & $\begin{array}{l}\text { Physio1 } \\
\text { (V1) }\end{array}$ & $\begin{array}{l}\text { Physio2 } \\
\text { (V2) }\end{array}$ \\
\hline Biological yield & -0.30 & 0.80 & 0.08 & 0.36 & 0.06 & 0.24 \\
\hline Spike yield & 0.66 & -0.30 & 0.26 & 0.36 & 0.20 & 0.24 \\
\hline Grain yield & 0.29 & -0.37 & 0.63 & 0.25 & 0.47 & 0.17 \\
\hline Harvest index & 0.34 & 0.39 & 0.70 & 0.04 & 0.52 & 0.03 \\
\hline Plant height & -0.50 & -0.56 & -0.31 & 0.25 & -0.23 & 0.17 \\
\hline Spike length & -0.37 & 0.79 & -0.37 & 0.74 & -0.21 & 0.50 \\
\hline Number of spikelet per spike & -0.28 & 0.57 & 0.05 & 0.64 & 0.03 & 0.44 \\
\hline Grain number per spike & 0.44 & -0.25 & 0.27 & 0.47 & 0.20 & 0.32 \\
\hline Thousand grain weight & 0.33 & 0.42 & 0.13 & 0.47 & 0.09 & 0.32 \\
\hline Correlation of canonical variables & $\begin{array}{c}0.75 \\
(\mathrm{U} 1, \mathrm{~V} 1)\end{array}$ & $\begin{array}{c}0.67 \\
(\mathrm{U} 2, \mathrm{~V} 2)\end{array}$ & & & & \\
\hline Canonical Correlation modified & $\begin{array}{c}0.59 \\
(\mathrm{U} 1, \mathrm{~V} 1)\end{array}$ & $\begin{array}{c}0.61 \\
(\mathrm{U} 2, \mathrm{~V} 2)\end{array}$ & & & & \\
\hline \multirow{2}{*}{$\begin{array}{c}\text { Physiological traits } \\
\text { (Physio) }\end{array}$} & \multicolumn{2}{|c|}{$\begin{array}{c}\text { Coefficients in } \\
\text { canonical variables }\end{array}$} & \multicolumn{2}{|c|}{$\begin{array}{l}\text { Correlation with } \\
\text { Physio variable }\end{array}$} & \multicolumn{2}{|c|}{$\begin{array}{l}\text { Correlation with } \\
\text { Agro variable }\end{array}$} \\
\hline & $\begin{array}{l}\text { Physio1 } \\
\text { (V1) }\end{array}$ & $\begin{array}{c}\text { Physio2 } \\
\text { (V2) }\end{array}$ & $\begin{array}{l}\text { Physio1 } \\
\text { (V1) }\end{array}$ & $\begin{array}{c}\text { Physio2 } \\
\text { (V2) }\end{array}$ & $\begin{array}{c}\text { Agro1 } \\
\text { (U1) }\end{array}$ & $\begin{array}{c}\text { Agro2 } \\
\text { (U2) }\end{array}$ \\
\hline RWC & 0.11 & -0.82 & -0.05 & 0.002 & -0.04 & 0.001 \\
\hline IWC & -1.8 & 0.60 & -0.23 & 0.73 & -0.17 & 0.49 \\
\hline LWC & 1.44 & 0.65 & 0.023 & 0.78 & 0.017 & 0.53 \\
\hline ELWL & -0.41 & 0.14 & 0.35 & -0.35 & -0.26 & -0.17 \\
\hline WSD & 0.63 & 0.045 & 0.63 & 0.13 & 0.47 & 0.09 \\
\hline
\end{tabular}

${ }^{2)}$ IWC: initial water content, RWC: relative water content, WSD: water saturated deficit, LWC: leaf water content, ELWL: excised leaf water loss. 
LWC $(r=1.44)$ and RWC $(r=-0.82)$ had the highest coefficients, respectively. The results for the interrelationship of agronomic and physiological traits can be used for an integrated selection index based on a combination of these traits that may provide useful criterion for improving drought tolerance in wheat. RWC is an indicator of water status and grain yield is increased if water retention capacities of wheat genotypes increase (Clarke and Townley-Smith 1986; Clarke and Richards 1988; Clarke et al. 1989; Sairam and Srivastava 2001; Kocheva and Georgiev 2003; Kumar and Sharma 2007; Nouri et al. 2011; Chakhchar et al. 2017; Ogbonnaya et al. 2017). Although canonical coefficients are artificial and have no physical meaning, correlations between canonical variates and their original associated variables can help supply meaning for canonical variates. In CCA, the first physiological canonical variable representing water saturated deficit (WSD) and excised leaf water loss (ELWL) strongly associated with variations in grain yield and harvest index under drought stress conditions. In a study, principle component analysis indicated that gain yield under drought stress condition had higher association with WSD and RWC as compared to other water status traits (Farshadfar and Ghasemi 2015). The second physiological variable showing initial water content (IWC) and leaf water content (LWC) variations was correlated with spike characteristics under drought stress conditions. Agro1 had relatively strong correlations with grain yield and harvest index while it had negative correlations with plant and spike lengths. These correlations imply plant height reduction possibly causes more allocation or retransferring of photosynthetic material to the spike under drought stress conditions (Reynolds et al. 2005). Phenotyping physiological traits as complement to agronomic traits helps in identifying selectable characteristics that accelerate wheat breeding aimed at increasing yield under drought stress conditions (Cattivelli et al. 2008; Fleury et al. 2010). In selecting drought-adaptive genotypes, it is helpful to choose physiologically trustworthy indicators and leaf water potential could be used as reliable reference indicator for breeding drought-tolerant cultivars (Chen et al. 2016). The association between high rate of osmotic adjustment (OA) and sustained yield or biomass under water-limited conditions across different cultivars of crop plants has been proved (Blum 2005). Since OA helps to maintain higher leaf relative water content (RWC) at low leaf water potential (LWP), it is evident that OA helps to sustain growth while the plant is meeting transpirational demand by reducing its LWP. Therefore, the analysis of joint variability of traits indicated that water status characters are of importance in crop growth cycle and that they were associated with variations in agronomic traits when droughts stress occurs at the generative stage of wheat growth.

\section{REFERENCES}

Ahmadizadeh M, Shahbazi H, Valizadeh M, Zaefizadeh M. 2011. Genetic diversity of durum wheat landraces using multivariate analysis under normal irrigation and drought stress conditions. Afr. J. Agric. Res. 6: 2294-2302.

Atkinson NJ, Urwin PE. 2012. The interaction of plant biotic and abiotic stresses: from genes to the field. J. Exp. Bot. 63: 3523-3543.

Araus JL, Slafer GA, Royo C, Serret MD. 2008. Breeding for yield potential and stress adaptation in cereals. CRC. Crit. Rev. Plant. Sci. 27: 377-412.

Barrs HD, Kozlowski TT. 1968. Determination of water deficits in plant tissues. Water Deficits Plant Growth 1: 235-368.

Bramel PJ, Hinz PN, Green DE, Shibles. 1984. Use of principal factor analysis in the study of three stems termination types of soybean. Euphytica. 33: 387-400.

Blum A. 2005. Drought resistance, water-use efficiency, and yield potential are they compatible, dissonant, or mutually exclusive? Aust. J. Agr. Res. 56: 1159-1168.

Cattivelli L, Rizza F, Badeck FW, Mazzucotelli E, Mastrangelo AM, Francia E, Marè C, Tondelli A, Stanca AM. 2008. Drought tolerance improvement in crop plants: An integrated view from breeding to genomics. Field Crops Res. 105: 1-14.

Chakhchar A, Wahbi S, Lamaoui M, Ferradous A, Mousadik AE, Ibnsouda-Koraichi S, et al. 2017. Physiological and biochemical traits of drought tolerance in Argania spinosa. J. Plant Interac. 10: 252-261.

Chen D, Wang S, Cao B, Cao D, Leng G, Li H, et al. 2016. Genotypic variation in growth and physiological response to drought stress and re-watering reveals the critical role 
of recovery in drought adaptation in maize seedlings. Front. Plant Sci. 7: 1-15.

Clarke JM. McCaig TN. 1982. Excised-leaf water retention capability as an indicator of drought resistance of Triticum genotypes. Can. J. Plant Sci. 62: 571-578.

Clarke JM, Richards RA. 1988. The effects of glaucousness, epicuticular wax, leaf age, plant height, and growth environment on water rates of the excised leaves. Can. J. Plant Sci. 68: 975-982.

Clarke JM, Romagosa I, Jana S, Srivastava JP, McCaig TN. 1989. Relationship of excised leaf water loss rate and yield of durum wheat in diverse environments. Can. J. Plant Sci. 69: 1075-1081.

Clarke TM, Townley-Smith TF. 1986. Heritability and relationship of excised-leaf water retention in durum wheat. Crop Sci. 26: 289-292.

Condon AG, Richards RA, Rebetzke GJ, Farquhar GD. 2004. Breeding for high water-use efficiency. J. Exp. Bot. 55: 2447-2460.

Dorostkar S, Dadkhodaie A, Heidari B. 2015. Evaluation of grain yield indices in hexaploid wheat genotypes in response to drought stress. Arch. Agr. Soil Sci. 61: 397-414.

Dorostkar S, Dadkhodaie A, Heidari B. 2016. Changes in biochemical characteristics in thirty-six Iranian wheat landraces in response to drought stress and their classification using multivariate analysis. J. Animal Plant Sci. 26: 1740-1749.

Ebrahimnejad S, Rameeh V. 2016. Correlation and factor analysis of grain yield and some important component characters in spring wheat genotypes. Cercetări Agronomice în Moldova. 1: 5-15.

Farshadfar E, Ghasemi M. 2015. Evaluation of drought tolerance in bread wheat using water relations and integrated selection index. J. Biodivers. Environ. Sci. 6: 77-84.

Fleury D, Jefferies S, Kuchel H, Langridge P. 2010. Genetic and genomic tools to improve drought tolerance in wheat. J. Exp. Bot. 61: 3211-3222.

Gian B, Jong RD, Gameda S. 2009. Multivariate analysis of water-related agroclimatic factors limiting spring wheat yields on the Canadian prairies. Europ. J. Agron. 30: 140-150.

Ghaed-rahimi L, Heidari B, Dadkhodaie A. 2015. Genotype $\times$ environment interactions for wheat grain yield and antioxidant changes in association with drought stress. Arch. Agr. Soil Sci. 61: 153-171.

Hamayun M, Afzali Khan S, Latif Khan A, Shinvari ZK, Hussain J, Sohn E, et al. 2010. Effect of salt stress on growth attributes and endogenous growth hormones of soybean cultivars Hwangkeumkong. Pak. J. Bot. 42: 3103-3112.

Hojjati MH, Boustani F. 2010. An assessment of groundwater crisis in Iran case study: Fars Province. Int. J. Soc. Behav. Educ. Economic, Business Ind. Eng. 4: 2066-2070.

Hotelling H. 1936. Relations between two sets of varieties. Biometrika. 28: 321-377.

Khaledian Z, Heidari B, Daneshnia N. 2014. Screening wheat landrace varieties for grain yield under water deficit conditions using drought tolerance indices. Int. J. Plant Soil Sci. 6: 763-776.

Kocheva K, Georgiev G. 2003. Evaluation of the reaction of two contrasting barley (Hordeum vulgare L.) cultivars in response to osmotic stress with PEG 6000. Bulg. J. Plant Physiol. Special Issue. 290-294.

Kumar A, Sharma SC. 2007. Genetics of excised-leaf water loss and relative water content in bread wheat (Triticum aestivum L.). Cereal Res. Comm. 35: 43-52.

Leila AA, Al-Khateeb SA. 2005. Statistical analysis of wheat yield under drought conditions. J. Arid Environ. 61: 483-496.

Mirtaheri SM, Paknejad F, Behdad M. 2015. The application of the multivariate analysis methods for some traits in wheat under drought stress. J. Agr. Sci. 60: 407-417.

Mora F, Castillo D, Lado B, Matus I, Poland J, Belzile F, et al. 2015. Genome-wide association mapping of agronomic traits and carbon isotope discrimination in a worldwide germplasm collection of spring wheat using SNP markers. Mol. Breed. 35: 69.

Mollasadeghi V, Imani AA, Shahryari R, Khayatnejad M. 2011. Classifying bread wheat genotypes by multivariable statistical analysis to achieve high yield under after anthesis drought. Middle-East J. Sci. Res. 7: 217-220.

Mwadzingeni L, Shimelis L, DJG Rees, Tsilo TJ. 2017. Genome-wide association analysis of agronomic traits in wheat under drought stressed and non-stressed conditions. PLoS One 12: e0171692.

Nouri A, Etminan A, Teixeira da Silva JA, Mohammadi R. 2011. Assessment of yield, yield-related traits and drought tolerance of durum wheat genotypes (Triticum 
turjidum var. durum Desf.). Aust. J. Crop Sci. 5: 8-16.

Ogbonnaya FC, Rasheed A, Okechukwu EC, Jighly A, Makdis

F, Wuletaw T, et al. 2017. Genome-wide association study for agronomic and physiological traits in spring wheat evaluated in a range of heat prone environments. Theor. Appli. Genet. DOI: 10.1007/s00122-017-2927-z.

Ordaz-Oritz JJ, Devaux M, Saulnier L. 2005. Classification of wheat varieties based on structural features of arabimoxylase as revealed by exndoxylanase treatment of flour and grain. J. Agr. Food Chem. 53: 8349-8356.

Qian B, De Jong R, Gameda S. 2009. Multivariate analysis of water-related agroclimatic factors limiting spring wheat yields on the Canadian prairies. Europ. J. Agron. 30: 140-150.

Reynolds M, Mujeeb-kazi A, Sawkins M. 2005. Prospects for utilizing plant-adaptive mechanisms to improve wheat and other crops in drought- and salinity-prone environments. Ann. Appl. Biol. 146: 239-259.

Reynolds M, Foulkes MJ, Slafer GA, Berry P, Parry AMJ, Snape JW, et al. 2009. Raising yield potential in wheat. J. Exp. Bot. 60: 1899-1918.

Rieseberg LH, Archer MA, Wayne RK. 1999. Transgressive segregation, adaptation and speciation. Heredity 83: 363-372.

Sangtarash MH. 2010. Responses of different wheat genotypes to drought stress applied at different growth stages. Pak. J. Biol. Sci. 13: 114-119.

Sairam RK, Srivastava GC. 2001. Water stress tolerance of wheat (Triticum aestivum L.): variations in hydrogen peroxide accumulation and antioxidant activity in tolerant and susceptible genotypes. J. Agron. Crop Sci. 186: 63-70.

Subhani GM, Hussain M, Ahmed J, Anwar J. 2011. Response of exotic wheat genotypes to drought stress. J. Agr. Res. 49: 293-305.

Tahmasebi S, Heidari B, Pakniyat H, Dadkhodaie A. 2015. Consequences of $1 \mathrm{BL} / 1 \mathrm{RS}$ translocation on agronomic and physiological traits in wheat. Cereal Res. Comm. 43: 554-566.

Tas S, Tas B. 2007. Some physiological responses of drought stress in wheat genotypes with different ploidy in Turkey. World J. Agric. Sci. 3: 178-183.

Ward JH. 1963. Hierarchical grouping to optimize an objective function. J. Am. Stat. Assoc. 58: 236-244.

Zakizadeh M, Moghaddam ME, Kahrizi D. 2010. Study on genetic variation and relationship between plant characteristics and grain yield in long spike bread wheat (Triticum aestivum L.) genotypes-using multivariate analysis. Iranian J. Crop Sci. 12: 18-30. 